\title{
Planktonic oligotrich ciliates in the NW Mediterranean: growth rates and consumption by copepods
}

\author{
M. T. Pérez*, J. R. Dolan, E. Fukai \\ Marine Microbial Ecology Research Group, Station Zoologique, BP 28, F-06230 Villefranche-sur-Mer, France
}

\begin{abstract}
In May 1995, the planktonıc ciliate community of the Ligurian Sea (NW Mediterranean) was dominated by 3 Strombidium species: a mixotroph $16 \mu \mathrm{m}$ in length, a heterotrophic species $15 \mu \mathrm{m}$ in length and a larger $(26 \mu \mathrm{m})$ heterotrophic species. Growth rates of these oligotrichs and their consumption by copepods were examined in 3 shipboard experiments during the JGOFS-France DYNAPROC cruise. Growth rates were estumated by means of $24 \mathrm{~h}$ incubations in seawater samples filtered through a $64 \mu \mathrm{m}$ mesh and apparent growth or disappearance rates were estimated in whole water samples and in incubated samples with copepods added. Ciliate community generation time ranged from 52 to $88 \mathrm{~h}$. Copepod predation was highest on the larger heterotrophic ciliate and higher on the nano-sized heterotrophic species relative to mixotrophic nanociliate. The net growth rates of the mixotroph in 'predator-free' water ranged from 0.2 to $0.4 \mathrm{~d}^{-1}$ compared to rates of 0.9 to $1.0 \mathrm{~d}^{-1}$ in samples with copepods added. Net growth rates of heterotrophic species ranged from 0.2 to $0.5 \mathrm{~d}^{-1}$. The higher mixotrophic growth rates when copepods were present was concomitant with the disappearance of heterotrophic microciliates $\left(2.2\right.$ to $9.0 \mathrm{ml}$ cleared of heterotrophic microciliates copepod ${ }^{-1} \mathrm{~h}^{-1}$, estimated clearance rates). While we found that mixotrophs, relative to heterotrophs, may be less subject to copepod predation, data and models suggests that mixotrophic oligotrichs have lower maxumal growth rates than similar-sized heterotrophic species.
\end{abstract}

KEY WORDS: Mixotrophy Strombidium Predation

\section{INTRODUCTION}

Marine planktonic ciliates are an ecologically important group; they dominate the microzooplankton in most marine systems (Beers et al. 1980) and serve as a trophic link between the microbial food web and metazoans, especially copepods (Sherr et al. 1986, Stoecker \& Capuzzo 1990, Gifford 1991). It is now recognised that many planktonic oligotrich ciliates contain chloroplasts and are mixotrophic (Stoecker et al. 1987, LavalPeuto \& Rassoulzadegan 1988, Stoecker et al. 1989). Mixotrophic ciliates obtain energy from both photosynthesis and phagotrophic feeding; they represent a variable fraction of the ciliate fauna in different marine systems (Stoecker 1991). For example, in the NW Mediterranean during autumn and winter, an average

•E-mail: perez@ccrv.obs-vlfr.fr of about $40 \%$ of the oligotrich species contain chloroplasts (Laval-Peuto \& Rassoulzadegan 1988) and during the spring, mixotrophs can occasionally approach $100 \%$ of total ciliate biovolume (Bernard \& Rassoulzadegan 1994). Despite the common occurrence of mixotrophs in estuarine and marine ecosystems, little is known about factors regulating their abundance or factors influencing their importance relative to heterotrophic species. Advantages of mixotrophy in foodpoor or oligotrophic environments are obvious but there are likely to be some costs involved with mixotrophy given the fact that such forms rarely achieve complete dominance

While the importance of oligotrichs in marine systems is recognised, very few field studies have provided estimates of oligotrich, either heterotrophic or mixotrophic, growth rates. To our knowledge, reports based on experimental studies of only 2 open-water 
marine systems are available: the North Atlantic (Verity et al. 1993) and the Peruvian upwelling system (Tumantseva \& Kopylov 1985); none exist for relatively oligotrophic systems such as the NW Mediterranean.

In this report we present the results of 3 field experiments designed to provide estimates of oligotrich growth rates for the NW Mediterranean. We used these experiments to compare heterotrophic and mixotrophic growth rates and the relative susceptibility of the different oligotrich types to predation by copepods. We also examined apparent growth capacities of mixotrophic and heterotrophic oligotrich ciliates on the basis of maximum reported growth rates available in the literature and summarise existing data on copepod consumption of oligotrichs.

\section{MATERIAL AND METHODS}

Experiments were carried out onboard the 'Suroit' during the JGOFS-France DYNAPROC cruise (Dynamics of Rapid Processes in the Water Column) in May 1995. Samples were taken at the JGOFS-France reference station DYFAMED $\left(43^{\circ} 25.2^{\prime} \mathrm{N}, 7^{\circ} 51.8^{\prime} \mathrm{E}_{\mathrm{i}}\right.$ NW Mediterranean) located approx. $50 \mathrm{~km}$ offshore from Nice, France. The water column depth of the station is about $2000 \mathrm{~m}$. Ciliate growth rates and grazing losses were estimated by monitoring changes in cell concentrations in predator-free seawater, in whole water with in situ concentrations of copepods, and in water to which copepods were added.

Experimental protocol. Water samples were taken with Go-flo bottles at $20 \mathrm{~m}$ depth. This depth was chosen as previous studies had indicated that it would probably yield a ciliate community about evenly divided between mixotrophs and heterotrophs (Dolan \& Marrasé 1995) After sampling, the following manipulations were performed to yield 3 distinct subsamples: 21 was passed through a $64 \mu \mathrm{m}$ nylon mesh to remove large zooplankton, 2 l remained untreated, and 2 l received the addition of 1.0 adult copepod females (Centropages) collected with a WP 2 plankton net. The treatments provided samples containing. (1) only small ciliates without copepods or large predacious ciliates; (2) whole water with approximately the in situ ciliate and copepod communities; (3) water with an increased concentration of copepods. Samples were assigned to 2 l polycarbonate bottles which were placed in a running seawater incubator with a neutral density screen removing $70 \%$ of incident illumination, corresponding roughly with the incident illumination at $20 \mathrm{~m}$ depth.

Samples for ciliate counts were taken at time zero and after $24 \mathrm{~h}$ (end of incubation). $500 \mathrm{ml}$ was removed from each bottle and preserved in acid Lugol's $12 \%$ final concentration) which minimizes cells losses relative to aldehyde fixatives (Stoecker et al. 1994). We used $2 \%$ acid Lugol's because a volume-to-carbon conversion factor exists (Putt \& Stoecker 1989). The principal disadvantage of acid Lugol's is that mixotrophic ciliates can be identified only from characteristics of gross morphology. To get round this problem a 1 I sample of whole water was taken prior to the experiments. $500 \mathrm{ml}$ was preserved in acid Lugol's for the determination of distinct ciliate morphospecies and the remaining $500 \mathrm{ml}$ fixed with $2 \%$ borate-buffered formaldehyde to identify by epifluorescence microscopy the mixotrophic forms among the morphospecies determined previously. At the end of the incubation after samples for ciliate counts were removed, the remaining water in the bottles with whole seawater and with added copepods was concentrated to $40 \mathrm{ml}$ over a $20 \mu \mathrm{m}$ nylon mesh and preserved with $2 \%$ acid Lugol's to allow estimation of copepod concentrations.

Experiments were run in triplicate for filtered and whole water samples and in duplicate for copepod additions. For each experiment, replicates represented consecutive repetitions of the entire procedure beginning with a new water bottle sample. Experiments were conducted on 3 dates: 11, 14 and 27 May 1995 and each time started in the morning between 07:30 and 08:40 h local time.

Sample processing and data analysis. For determination of trophic types, $500 \mathrm{ml}$ subsamples, fixed with formaldehyde or acid Lugol's, were concentrated via sedimentation in $500 \mathrm{ml}$ graduated glass cylinders. After $4 \mathrm{~d}$ the upper $400 \mathrm{ml}$ of the sample was gently siphoned and the bottom concentrated $100 \mathrm{ml}$ settled in a standard settling chamber. Both samples were examined in parallel with a Zeiss Axiovert 35 inverted microscope. Ciliates were identified to genus when possible according to Montagnes \& Lynn (1991) from the acid Lugol's preserved sample. The determination of trophic type (mixotrophic or heterotrophic) was made by examining the aldehyde-fixed sample using epifluorescence microscopy.

Time zero and $24 \mathrm{~h}$ samples from the experiments (50 or $100 \mathrm{ml}$ ) were settled and the entire surface of the settling chamber examined at $200 \times$ with an inverted microscope. Ciliates of distinct morphospecies, determined using the double analysis, were counted. Copepod abundances were determined from the sample concentrated over $20 \mu \mathrm{m}$ mesh Nitex. The concentrate was transferred into a settling chamber and the chamber surface was scanned at $100 \times$ with an inverted microscope. Preserved copepods were identified by Suzanne Nival (Station Zoologique)

Rates of ciliate growth and copepod grazing were calculated from ciliate counts following the system of equations of Frost (1972): 


$$
\begin{aligned}
& \mathrm{k}=\ln \left(C_{1} / C_{0}\right) /\left(t_{1}-t_{0}\right) \\
& \mathrm{g}=\mathrm{k}-\left[\ln \left(C_{1} * / C_{0} *\right) /\left(t_{1}-t_{0}\right)\right]
\end{aligned}
$$

where $\mathrm{k}$ is the growth constant, $C_{1}$ and $C_{0}$ are ciliate concentrations (cells $\mathrm{ml}^{-1}$ ) in the bottles without grazers at times $t_{1}$ and $t_{0}$ respectively, $g$ is the grazing coefficient and $C_{1}{ }^{*}$ and $C_{0}{ }^{*}$ are ciliate concentrations in cells $\mathrm{ml}^{-1}$ at $t_{1}$ and $t_{0}$ in bottles with copepods.

\section{RESULTS}

\section{Experimental conditions}

Fig. 1 shows depth profiles of temperature, density, chlorophyll a (chl a) and ciliates on the 3 experimental dates. In May 1995, the water column was beginning to stratify with a weak density gradient and a considerable temperature gradient, ranging from 17.4 to $13.3^{\circ} \mathrm{C}$ on 11 May and from 16 to $13.3^{\circ} \mathrm{C}$ on 14 and 27 May. The different experimental conditions during the incubations are summarised in Table 1. Illumination was low due to cloud cover during incubations especially on 27 May $\left(213.23 \mathrm{~W} \mathrm{~m}^{-2} \mathrm{~h}^{-1}\right.$ average during daylight hours). Water temperature at $20 \mathrm{~m}$ ranged from $13.9^{\circ} \mathrm{C}$ (14 May) to $15.5^{\circ} \mathrm{C}$ (27 May) and chl a concentration, the most variable parameter, ranged from $0.28 \mu \mathrm{g} \mathrm{l}^{-1}$ on 11 May to $1.15 \mu \mathrm{g}^{-1}$ on 14 May. Similar to chlorophyll, cyanobacteria and nanoflagellates were less abundant on 27 May compared to 14 May. The highest chl a concentration at the sampling depth of $20 \mathrm{~m}$ on 14 May was due to strong winds on 13 May moving the chl a peak up from 30 to $20 \mathrm{~m}$. Copepods in whole water were a mixture of approx. 50\% Oithona sp. and 50\% small calanoids (Pseudocalanus and Clausocalanus spp.).

\section{Generation time and growth rates}

Community generation times (Table 2) varied from $51.9 \mathrm{~h}$ on 14 May to $87.8 \mathrm{~h}$ on 27 May. On all 3 dates, the ciliate community was dominated by 3 Strombidium species with metabolic charac-
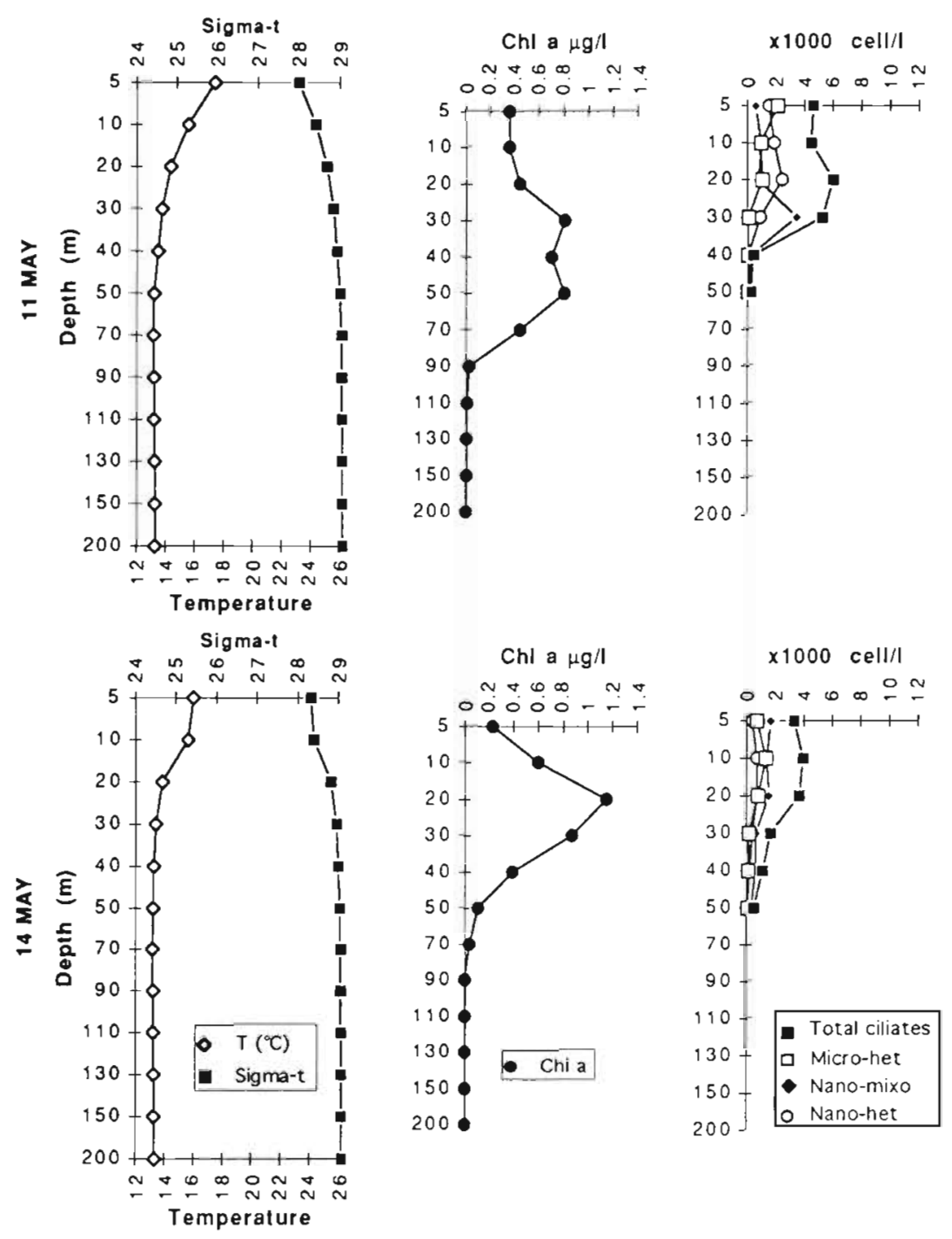

Sigma-1

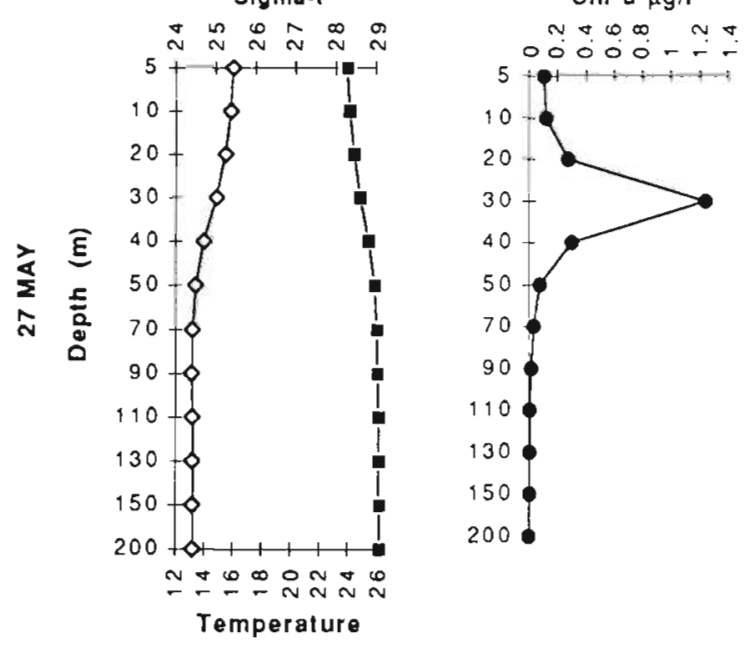

$\times 1000 \mathrm{cell} / \mathrm{I}$

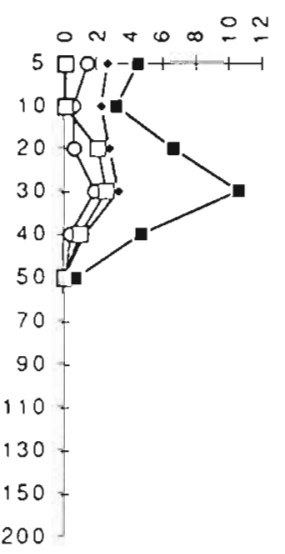

Fig. 1. Depth profiles of physical and biological parameters at the beginning of incubations on the 3 experimental dates in 1995. T: temperature; Chl a: chlorophyll a concentration 
Table 1. Incubation experimental conditions Chlorophyll $a_{1}$ illumination and temperature values at $20 \mathrm{~m}$ at time zero. Averaged concentration $(n=3)$ in cells $\mathrm{ml}^{-1}$ of cyanobacteria, heterotrophic nanoflagellates (HNF), and autotrophic nanoflagellates (ANF) in the experimental bottles (whole water) at time zero

\begin{tabular}{|c|c|c|c|c|c|c|}
\hline Date & $\begin{array}{c}\text { Chl a } \\
\left(\mu \mathrm{g} \mathrm{l}^{-1}\right)\end{array}$ & $\begin{array}{l}\text { llumination } \\
\left(\mathrm{W} \mathrm{m}^{-2} \mathrm{~h}^{-1}\right)\end{array}$ & $\begin{array}{l}\text { Temp. } \\
\left({ }^{\circ} \mathrm{C}\right)\end{array}$ & $\begin{array}{c}\text { Cyanobacteria } \\
\text { (SD) }\end{array}$ & $\begin{array}{l}\text { HNF } \\
\text { (SD) }\end{array}$ & $\begin{array}{l}\text { ANF } \\
\text { (SD) }\end{array}$ \\
\hline 11 May & 0.28 & 251.87 & 14.3 & $1.78 \times 10^{5}\left(2.90 \times 10^{4}\right)$ & No data & No data \\
\hline 14 May & 1.15 & 392.48 & 13.9 & $1.07 \times 10^{5}\left(3.62 \times 10^{4}\right)$ & $13.4 \times 10^{2}\left(5.64 \times 10^{2}\right)$ & $12.9 \times 10^{2}\left(6.49 \times 10^{2}\right)$ \\
\hline $27 \mathrm{May}$ & 0.44 & 213.23 & 15.5 & $0.64 \times 10^{5}\left(2.05 \times 10^{4}\right)$ & $486 \times 10^{2}\left(1.11 \times 10^{2}\right)$ & $3.36 \times 10^{2}\left(1.33 \times 10^{2}\right)$ \\
\hline
\end{tabular}

teristics and linear dimensions as given in Table 2. Figs. 2 \& 3 show, respectively, the initial and final concentrations of ciliates and the growth rates of dominant species in different treatments during experiments.
The net growth rate of the mixotrophic nanociliate in the $<64 \mu \mathrm{m}$ fraction ranged from a negative rate during the first experiment (11 May) to 0.41 and $0.24 \mathrm{~d}^{-1}$ for the second and third experiments (1.4 and 27 May
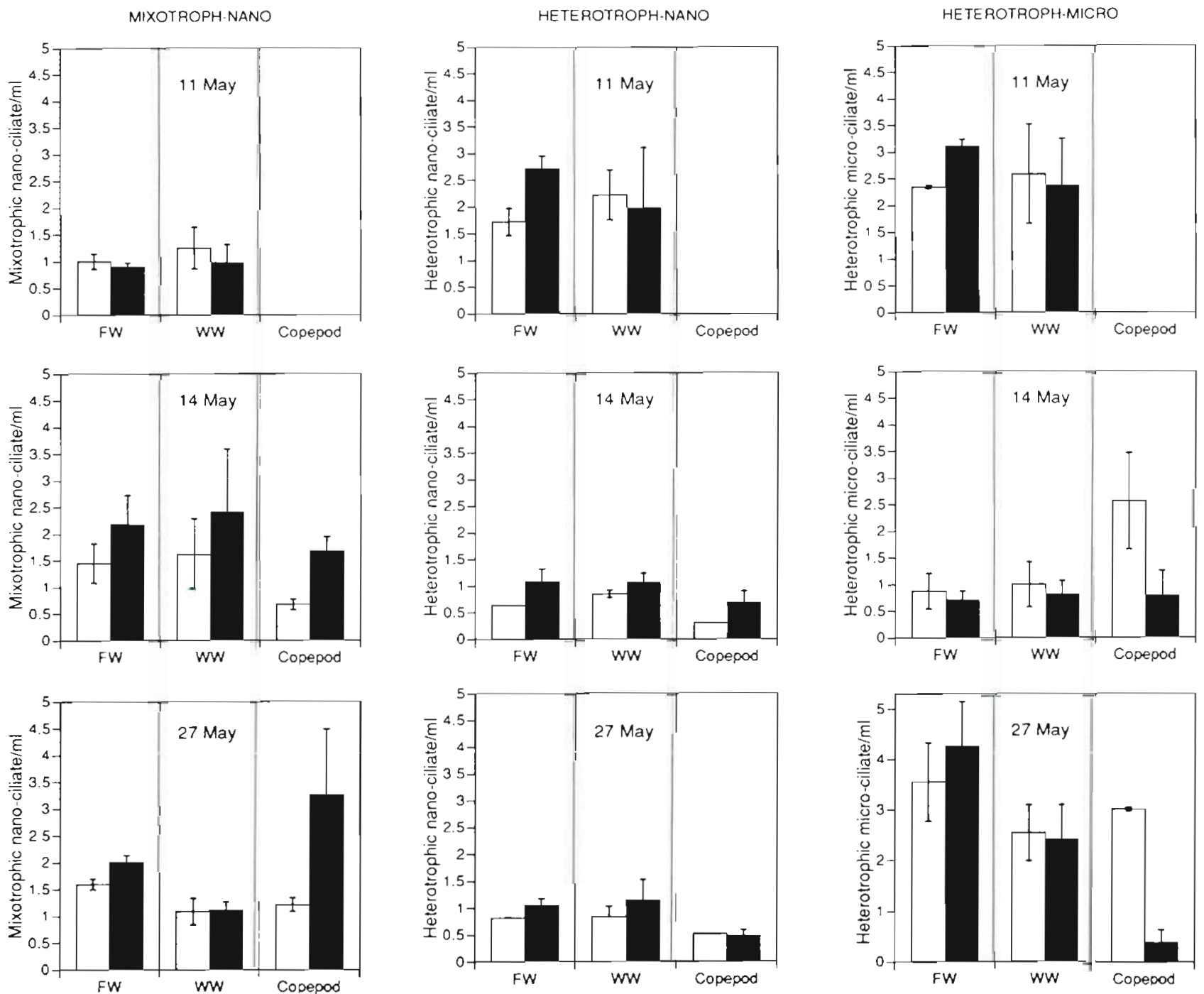

Fig. 2. Initual (open bars) and final (solid bars) ciliate concentrations in experimental bottles during incubations conducted on 11, 14 and 27 May. FW: water filtered through a $64 \mu \mathrm{m}$ mesh; WW: whole water; Copepod: water with copepods added. Values are means of 3 replicates, except for Copepod (means of 2 replicates); error bars are standard deviation. Missing values for Copepod on 11 May correspond to missing samples on this date 
Table 2. Community generation time ( $h$ ) and dominant species growth rate $\left(\mathrm{d}^{-1}\right)$ and generation time (h) estimated in water filtered through a $64 \mu \mathrm{m}$ mesh. T0: ciliate community concentration in cells $\mathrm{ml}{ }^{1}$ at time zero. $\mathrm{L} \times \mathrm{W}$ : length $\times$ width ( $\mu \mathrm{m}$ )

\begin{tabular}{|c|c|c|c|c|c|c|c|c|}
\hline Date & $\mathrm{n}$ & TO (SD) & $\begin{array}{l}\text { Community } \\
\text { generation time (SD) }\end{array}$ & $\begin{array}{l}\text { Dommant } \\
\text { species }\end{array}$ & Metabolism & $L \times W$ & $\begin{array}{l}\text { Growth } \\
\text { rate (SD) }\end{array}$ & $\begin{array}{l}\text { Generation } \\
\text { time (SD) }\end{array}$ \\
\hline $11 \mathrm{May}$ & $\begin{array}{l}2 \\
2 \\
2\end{array}$ & $5.25(0.35)$ & $69.7(20.6)$ & $\begin{array}{l}\text { Strombidium sp. a } \\
\text { Strombidium sp. b } \\
\text { Strombidium sp. c }\end{array}$ & $\begin{array}{l}\text { Mixotrophic } \\
\text { Heterotrophic } \\
\text { Heterotrophic }\end{array}$ & $\begin{array}{l}16 \times 10 \\
15 \times 15 \\
26 \times 18\end{array}$ & $\begin{array}{l}\text { No growth } \\
0.46(0.23) \\
0.22(0.06)\end{array}$ & $\begin{array}{l}\text { No growth } \\
41.6(21.2) \\
80.5(24.7)\end{array}$ \\
\hline 14 May & $\begin{array}{l}3 \\
3 \\
3\end{array}$ & $3.11(0.53)$ & $51.9(4.8)$ & $\begin{array}{l}\text { Strombidium sp. a } \\
\text { Strombidium sp. b } \\
\text { Strombidium sp. c }\end{array}$ & $\begin{array}{l}\text { Mixotrophic } \\
\text { Heterotrophic } \\
\text { Heterotrophic }\end{array}$ & $\begin{array}{l}16 \times 10 \\
15 \times 15 \\
26 \times 18\end{array}$ & $\begin{array}{l}0.41(0.07) \\
0.52(0.21) \\
\text { No growth }\end{array}$ & $\begin{array}{l}41.2(8.03) \\
36.0(15.0) \\
\text { No growth }\end{array}$ \\
\hline 27 May & $\begin{array}{l}3 \\
3 \\
3\end{array}$ & $6.64(0.66)$ & $87.8(38.8)$ & $\begin{array}{l}\text { Strombidium sp. a } \\
\text { Strombidium sp. b } \\
\text { Strombidium sp. c }\end{array}$ & $\begin{array}{l}\text { Mixotrophic } \\
\text { Heterotrophic } \\
\text { Heterotrophic }\end{array}$ & $\begin{array}{l}16 \times 10 \\
15 \times 15 \\
26 \times 18\end{array}$ & $\begin{array}{l}0.24(0.005) \\
0.26(0.14) \\
0.19(0.18)\end{array}$ & $\begin{array}{l}69.8(1.48) \\
76.5(33.2) \\
87.5(92.4)\end{array}$ \\
\hline
\end{tabular}

respectively). Net growth rates of mixotrophs in whole water ranged from a negative rate on 11 May to 0.38 and $0.03 \mathrm{~d}^{-1}$ on 14 and 27 May, respectively. For the 2 heterotrophic species, net growth rate in filtered seawater was between 0.26 and $0.46 \mathrm{~d}^{-1}$ for nanociliate and between 0.19 and $0.22 \mathrm{~d}^{-1}$ for the microciliate. The growth rate of the heterotrophic nanociliate in whole water was negative on 11 May and ranged from 0.20 to $0.30 \mathrm{~d}^{-1}$ on 14 and 27 May respectively. Heterotrophic microciliates did not grow in whole water. The highest net growth rates for nanociliates (both mixo- and heterotrophic) in filtered water were found on 14 May, coinciding with no growth of the heterotrophic microsized oligotrich.

The highest growth rates for both of the nano-sized oligotrichs were estimated from samples with increased copepod concentrations (Fig. 3). On 14 May the average of the apparent growth rate for the mixotrophic form in samples with added copepods was $0.93 \mathrm{~d}^{-1}, 2$-fold greater than the $0.41 \mathrm{~d}^{-1}$ found without added copepods. For the heterotrophic nanociliate growth rate ranged from $0.52 \mathrm{~d}^{-1}$ without copepods to
$0.86 \mathrm{~d}^{-1}$ in bottles with copepods added. On 27 May the average apparent growth rate of mixotrophic ciliates was $1.03 \mathrm{~d}^{-1}$ in samples with copepods added relative to $0.24 \mathrm{~d}^{-1}$ in filtered samples. In both cases, increase in apparent growth rate was concomitant with the disappearance of microheterotrophic species in the bottles.

\section{Copepod grazing}

A surprising result was that copepod grazing rates were higher on the heterotrophic species, whether micro- or nano-sized (Table 3). Although some positive filtration rates on the nano-sized mixotroph were recorded, they were always less than those estimated on heterotrophic oligotrichs. For example, for the May 11 experiment a filtration rate of $0.54 \mathrm{ml}$ copepod ${ }^{-1} \mathrm{~h}^{-1}$ was estimated for mixotrophic nanociliates from whole water samples, compared to 1.89 and $1.26 \mathrm{ml}$ copepod $^{-1} \mathrm{~h}^{-1}$ on the nano- and microheterotrophs, respectively. Unfortunately, for this first experiment we have
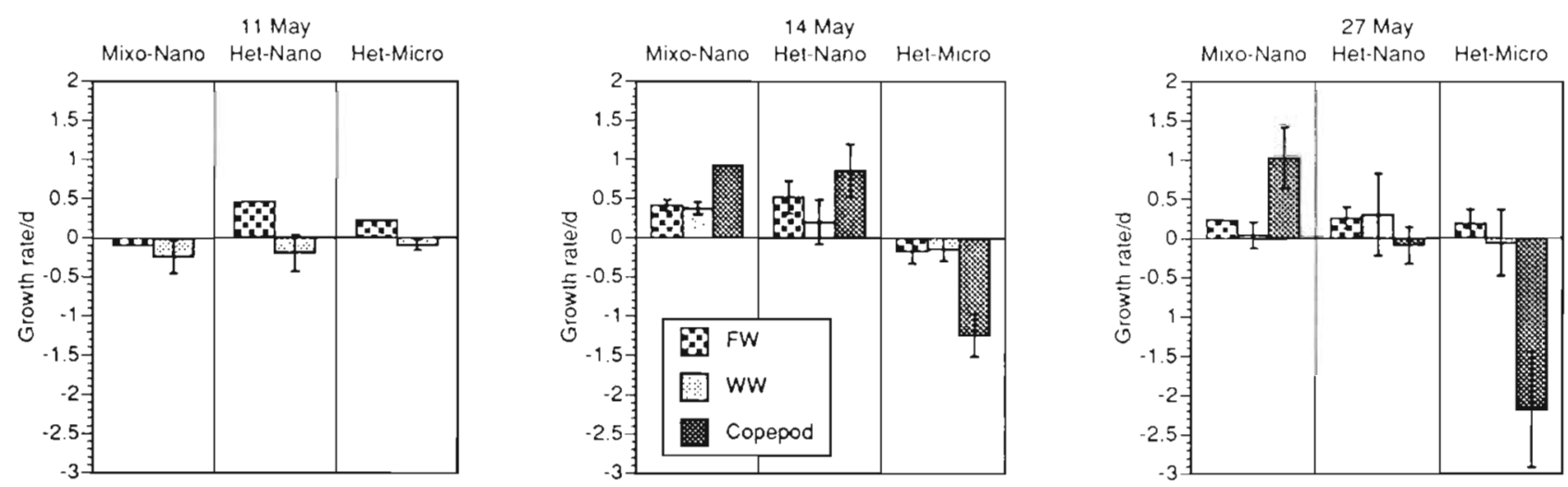

Fig. 3. Growth rate per day of different ciliate categories, estimated in water filtered through a 64 mm mesh (FW) and in bottles with grazers (whole water (WW) and water with copepods added (Copepod)], during the experiments conducted on 11, 14 and 27 May. Values are means of 3 replicates, except for Copepod (means of 2 replicates); error bars are standard deviation. Missing values for Copepod on 11 May correspond to missing samples on this date 
Table 3 . Summary data of copepod grazing experiment. $\mu$ : ciliate growth rate in control bottles (filtered water). G (grazing rate) and $\mathrm{F}$ (filtration rate in $\mathrm{ml}$ copepod ${ }^{-1} \mathrm{~h}^{-1}$ ) were estimated in both kind of grazer bottles: whole water and water with copepods added. Rep: replicate number. n: number of nauplii or copepods $l^{-1}$. nf: no filtration. -: samples lacking

\begin{tabular}{|c|c|c|c|c|c|c|c|c|c|}
\hline \multirow[t]{2}{*}{ Expt } & \multirow[t]{2}{*}{ Ciliate category } & \multirow[t]{2}{*}{ Rep } & \multirow{2}{*}{$\begin{array}{c}\text { Control (FW) } \\
\mu\left(\mathrm{h}^{-1}\right)\end{array}$} & \multicolumn{3}{|c|}{ Grazer (whole water) } & \multicolumn{3}{|c|}{ Grazer (copepod) } \\
\hline & & & & $G\left(h^{-1}\right)$ & $\mathrm{n}$ & $\mathrm{F}$ & $G\left(h^{-1}\right)$ & $\mathrm{n}$ & $\mathrm{F}$ \\
\hline \multirow[t]{9}{*}{11 May } & Mixotroph-Nano & 1 & - & - & - & - & - & - & - \\
\hline & & 2 & No growth & Nograzing & $5.5 / 4.5$ & nf & - & - & - \\
\hline & & 3 & 0.0022 & 0.0108 & $9 / 11$ & 0.54 & - & - & - \\
\hline & Heterotroph-Nano & 1 & - & - & - & - & - & - & - \\
\hline & & 2 & 0.0261 & 0.0191 & $5.5 / 4.5$ & 1.91 & - & - & - \\
\hline & & 3 & 0.0123 & 0.0372 & $9 / 11$ & 1.86 & - & $\sim$ & - \\
\hline & Heterotroph-Micro & 1 & - & - & - & - & - & - & - \\
\hline & & 2 & 0.0110 & 0.0250 & $5.5 / 4.5$ & 2.50 & - & - & - \\
\hline & & 3 & 0.0071 & 0.0004 & $9 / 11$ & 0.02 & - & - & - \\
\hline \multirow[t]{9}{*}{14 May } & Mixotroph-Nano & 1 & 0.0187 & 0.0038 & $9 / 6$ & 0.25 & No grazing & $9 / 11$ & nf \\
\hline & & 2 & 0.0191 & No grazing & $12 / 8$ & $\mathrm{nf}$ & No grazing & $12 / 13$ & $\mathrm{nf}$ \\
\hline & & 3 & 0.0137 & 0.0004 & $95 / 3.5$ & 0.03 & - & - & - \\
\hline & Heterotroph-Nano & 1 & 0.0207 & 0.0254 & $9 / 6$ & 1.69 & No grazing & $9 / 11$ & $\mathrm{nf}$ \\
\hline & & 2 & 0.0132 & No grazing & $12 / 8$ & $\mathrm{nf}$ & No grazing & $12 / 13$ & $\mathrm{nf}$ \\
\hline & & 3 & 0.0308 & No grazing & $9.5 / 3.5$ & $\mathrm{nf}$ & - & - & - \\
\hline & Heterotroph-Micro & 1 & No growth & No grazing & $9 / 6$ & $\mathrm{nf}$ & 0.0542 & $9 / 11$ & 2.71 \\
\hline & & 2 & No growth & 0.0456 & $12 / 8$ & 2.28 & 0.0423 & $12 / 13$ & 1.69 \\
\hline & & 3 & No growth & 0.0006 & $9.5 / 3.5$ & 0.05 & - & - & - \\
\hline \multirow[t]{9}{*}{27 May } & Mixotroph-Nano & 1 & 0.0097 & 0.0142 & $5 / 1$ & 2.37 & No grazing & $5 / 6$ & $\mathrm{nf}$ \\
\hline & & 2 & 0.0101 & 0.0008 & $4 / 2$ & 0.13 & No grazing & $4 / 7$ & nf \\
\hline & & 3 & 0.0099 & 0.0096 & $6.6 / 1.2$ & 1.23 & - & - & - \\
\hline & Heterotroph-Nano & 1 & 0.0066 & No grazing & $5 / 1$ & $\mathrm{nf}$ & 0.0175 & $5 / 6$ & 1.59 \\
\hline & & 2 & 0.0082 & 0.0163 & $4 / 2$ & 2.72 & 0.0052 & $4 / 7$ & 0.47 \\
\hline & & 3 & 0.0172 & 0.0035 & $6.6 / 1.2$ & 0.45 & - & - & - \\
\hline & Heterotroph-Micro & 1 & 0.0002 & No grazing & $5 / 1$ & $\mathrm{nf}$ & 0.1131 & $5 / 6$ & 10.3 \\
\hline & & 2 & 0.0152 & 0.0375 & $4 / 2$ & 6.25 & 0.0849 & $4 / 7$ & 7.72 \\
\hline & & 3 & 0.0079 & 0.0187 & $6.6 / 1.2$ & 2.40 & - & - & - \\
\hline
\end{tabular}

no data from bottles with copepods added due to loss of samples.

On 14 May, estimated filtration rates on mixotrophic and heterotrophic nanociliates from whole water were 0.14 and $1.69 \mathrm{ml}$ copepod $^{-1} \mathrm{~h}^{-1}$, respectively. Grazing on these species was not detected in bottles with copepods added. In contrast, average filtration rates of 1.17 and $2.20 \mathrm{ml} \mathrm{copepod}^{-1} \mathrm{~h}^{-1}$ were calculated on heterotrophic microciliates from bottles with whole water and with increased copepod concentrations, respectively.

For the May 27 experiment, average filtration rate of $1.24 \mathrm{ml} \mathrm{copepod}^{-1} \mathrm{~h}^{-1}$ was calculated on mixotrophic nanociliates with natural copepod concentrations and no filtration was detected in water with increased copepod concentrations. Declines in heterotrophic nanociliates gave average filtration rate estimates of $1.60 \mathrm{ml}$ copepod ${ }^{-1} \mathrm{~h}^{-1}$ with natural copepod concentrations and $1.03 \mathrm{ml}$ copepod ${ }^{-1} \mathrm{~h}^{-1}$ with increased copepod concentrations. Changes in heterotrophic microciliate concentrations indicated lower copepod filtration rates in whole water relative to water with copepods added, from 4.33 to $9.01 \mathrm{ml}$ copepod ${ }^{-1} \mathrm{~h}^{-1}$, respectively.

\section{DISCUSSION}

Ciliate growth rates estimated from in situ incubations are not exempt from artefacts due to containment effects, accumulation of waste products, food depletion or excesses (Leakey et al. 1994). Fractionation, used to eliminate large predators, may cause cell damage and alter ciliate growth or decrease ciliate concentration relative to their food (reviewed in Landry 1994). In our experiments, ciliate community concentrations at time zero did not significantly differ between the filtered sample and the untreated sample ( $t$-test), but we were not able to assess the physiological state of cells after fractionation. Some of our data suggest that fractionation may have injured some species. For example, the autotrophic ciliate Mesodinium rubrum, present during the 27 May incubation, did not grow in the fractionated sample but we found an average growth rate of $0.59 \mathrm{~d}^{-1}$ in whole water during this experiment. While this indicates that our growth estimates based on water filtered through a $64 \mu \mathrm{m}$ mesh may be underestimates, the rates estimated from whole water and samples to which copepods were added should not have been affected. 
Ciliate community generation time in the NW Mediterranean during May ranged from 52 to $88 \mathrm{~h}$. These growth rates are somewhat higher than the generation time of $80 \mathrm{~h}$ estimated for Catalan Sea ciliates in June, based on simple considerations of chl a concentration and temperature (Dolan \& Marrasé 1995), but somewhat lower than recent estimates for other marine systems, based on ciliate growth in size-fractionated samples. For example, the ciliate community generation time in Plymouth Sound, UK (Leakey et al. 1994), ranged from 29 to $52 \mathrm{~h}$ depending on the size of the mesh used. Ciliate community generation time in the North Atlantic during the spring bloom ranged from 18.5 to 55.4 h (Verity et al. 1993). Water temperature was roughly similar in all 3 studies considered (13 to $16^{\circ} \mathrm{C}$ ), but in our experiments, chlorophyll concentrations averaged about $0.5 \mathrm{\mu g} \mathrm{l}^{-1}$ (Table 1) compared to $2.5 \mathrm{\mu g} \mathrm{l}^{-1}$ in the North Atlantic study (Verity et al. 1993) or $1.5 \mathrm{\mu g} \mathrm{l}^{-1}$ in the Plymouth Sound experiments (Leakey et al. 1994). Thus, our values for community generation times (Table 2) appear reasonable considering water temperature and chl a concentrations. In our incubations, the shortest generation time was found on 14 May when chl a concentration and illumination were highest.

We found that the mixotrophic nanociliate grew at rates similar to the heterotrophic nanociliate species, 0.41 and $0.52 \mathrm{~d}^{-1}$, respectively, on $14 \mathrm{May}$ and 0.24 and $0.26 \mathrm{~d}^{-1}$, respectively, on $27 \mathrm{May}$, and in general faster than the larger heterotrophic microciliate species. Nevertheless, there was no net growth of the mixotroph during the first incubation. Net growth rates of the mixotrophic nanociliate in water filtered through a $64 \mu \mathrm{m}$ mesh were higher for experiments in which chl a concentrations were higher, while net growth of heterotrophic microciliates was lower. In addition, growth rates of mixotrophic ciliates seemed to be higher when copepods were added; we obtained net growth rates 2 -fold higher than in the filtered sample (Fig. 3). While fractionation may lower growth rate estimates because it damages cells, increases in net growth rates in samples to which copepods were added, relative to untreated water, are probably due to the effects of copepods. We do not know if such effects were direct (e.g. ammonium excretion) or indirect (e.g. predation on a competitor). However, it is noteworthy that mixotrophic growth occurred when the density of heterotrophic microciliates was greatly reduced, and that corresponded with an increased presence of copepods. Our observations support a hypothesis of competition between mixo- and heterotrophic species in experimental bottles that is balanced by copepod grazing which is higher on the heterotrophic forms.

Estimated filtration rates on heterotrophic microciliates from bottles with increased copepod concentra- tions (range 2.20 to $9.01 \mathrm{ml}$ copepod ${ }^{-1} \mathrm{~h}^{-1}$ ) were similar to rates calculated for copepods in bottles with natural copepod concentrations (range 1.17 to $4.33 \mathrm{ml}$ copepod $\left.^{-1} \mathrm{~h}^{-1}\right)$. The rates estimated correspond with most previous reports for small calanoid copepods feeding on ciliates (Table 4). Clearance rates on heterotrophic nanociliates were lower $(1.03$ and $1.73 \mathrm{ml}$ copepod $^{-1} \mathrm{~h}^{-1}$ with natural and increased copepod concentrations, respectively) but still in the range reported by Gifford \& Dagg (1988) for small oligotrichs. The somewhat higher clearance rate estimates for the bottles to which adult copepods were added are probably due to a reduction in the relative importance of naupliar stages in the 'copepods added' bottles as clearance rates for naupliar stages can be up to 2 orders of magnitude lower relative to adults (Berggreen et al. 1988)

In our experiments, copepod grazing on the mixotrophic nanociliate was low with natural copepod concentrations (avg. of $0.75 \mathrm{ml}$ copepod ${ }^{-1} \mathrm{~h}^{-1}$ ) and undetectable with increased copepod concentrations. As filtration rates of calanoid copepods are related to prey size (e.g. Frost 1972, Tiselius 1989) one explanation could be its small size but there was significant grazing on the similar-sized heterotrophic nanociliate. The particle size corresponding to $100 \%$ filtration efficiency for adult Centropages is $20 \mu \mathrm{m}$ (Nival \& Nival 1973). Based purely on considerations of size alone, for both the mixotrophic and heterotrophic nanociliates present in our study, the filtration efficiency was probably around 80 to $90 \%$, based on the data of Nival \& Nival (1973) for C. typicus. On this basis, we could explain the lower filtration rates estimated on heterotrophic nanociliates relative to heterotrophic microciliates. However, size considerations do not explain the differences in predation losses suffered by the heterotrophic nano-oligotrich compared to the mixotrophic nanooligotrich.

A possible explanation for the difference in mortality rates between the mixotrophic and heterotrophic species of a similar size is a difference in swimming pattern or higher swimming speeds. Jonsson \& Tiselius (1990) reported that the autotrophic Mesodinium rubrum was cleared more than 6 times less efficiently than Strombidium spiralis because of its swimming behaviour (rapid short jumps after immobility). As rapid jumps are known to be very expensive metabolically (Gilbert 1994), this suggests that exploiting photosynthesis allows costly predationresistant behaviour. Crawford (1992) noted that many fast swimming ciliates harbour algal endosymbionts or retain plastids. Furthermore, among oligotrich species studied by Buskey et al. (1993), the highest swimming speeds corresponded to 2 mixotrophic forms (Laboed strobila and S. conicum). However, it 
Table 4. Copepod filtration rates on ciliates. [C]: ciliate concentration $\left(\mathrm{m}^{-1}\right)$. V: prey volume $\left\{10^{3} \mu \mathrm{m}^{3}\right)$. F: filtration rate $(\mathrm{ml}$ copepod $\left.{ }^{-1} \mathrm{~h}^{-1}\right)$. Copepods are adult individuals otherwise indicated. Ciliate species in bold characters are mixotrophic or phototrophic

\begin{tabular}{|c|c|c|c|c|c|}
\hline Copepod species & Prey & {$[\mathrm{C}]$} & v & $\mathrm{F}$ & Source \\
\hline \multicolumn{6}{|l|}{ Marine calanoid copepods } \\
\hline \multirow[t]{5}{*}{ Acartia clausi } & Favella tarakaensis & 0.30 & $736.5^{\mathrm{d}}$ & 1.97 & Ayukai (1987) \\
\hline & Helicosomella fusitormis & $0.77-7.52$ & $34.5^{\circ}$ & $0.30-0.90$ & Ayukai (1987) \\
\hline & Natural assemblage & $0.20-0.80$ & - & $1.15-2.19$ & Tiselius (1989) \\
\hline & Strombrdium sulcatum & 3.3 & 13.9 & $1.43-26.3$ & Wiadnyana \& Rassoulzadegan (1989) \\
\hline & Natural assemblage & 1.73 & - & $0.41-0.44$ & Turner \& Graneli (1992) \\
\hline A. hudsonica & Eutıntinnus pectinus & $6.6-8.3$ & $118^{\mathrm{b}}$ & $0.19-0.38$ & Turner \& Anderson (1983) \\
\hline \multirow[t]{13}{*}{ A. tonsa } & Favella panamensis & $0.25-1.0 \quad 1$ & 1575.0 & 4.44 & Robertson (1983) \\
\hline & Tintinnopsis tubulosa & $0.25-2.0$ & 140.4 & $3.96-12.0$ & Robertson (1983) \\
\hline & Favella sp. & $1.0-4.0$ & 195 & 2.8 & Stoecker \& Sanders $(1985)$ \\
\hline & Strombidium $\mathrm{sp}$ & $3.8-4.1$ & $16.3^{\mathrm{b}}$ & $2.54-3.08$ & Stoecker \& EgIoff (1987) \\
\hline & Strobilidium sp. & 1.7 & $47.4^{b}$ & 1.92 & Stoecker \& Egloff (1987) \\
\hline & Favella sp. & $0.2-2.5$ & 195 & $0.29-10.4$ & Stoecker \& Egloff (1987) \\
\hline & Tintunnopsis sp. & $2.3-2.8$ & $52.3^{b}$ & $1.21-2.79$ & Stoecker \& Egloff (1987) \\
\hline & Balanionsp. & $5.0-4.6$ & $9.5^{b}$ & $4.21-4.42$ & Stoecker \& Egloff (1987) \\
\hline & Natural assemblage & $3.7-21.8$ & - & $1-7$ & Gifford \& Dagg (1988) \\
\hline & Strobilidium spiralis & $0.5-1.0$ & 150 & 3.58 & Jonsson \& Tiselius (1990) \\
\hline & Strombidium reticulatum & n $2.0-4.0$ & 16 & $1.96^{\circ}$ & Jonsson \& Tiselius (1990) \\
\hline & Mesodinium rubrum & $1.0-2.0$ & 30 & 0.625 & Jonsson \& Tiselius (1990) \\
\hline & Ciliates $>10 \mu \mathrm{m}$ & $3.36-20.36$ & - & $1.1-1.0$ & Gitford \& Dagg (1991) \\
\hline \multirow[t]{2}{*}{ (Nauplius-post naupliar) } & Natural assemblage & $0.40-30.3$ & - & $0.03-0.97$ & Dolan (1991) \\
\hline & S. sulcatum & 25 & 14 & $-4^{4}$ & Kiorboe et al. (1.996) \\
\hline Acartia spp. & Natural assemblage & $-0.13-20$ & -. & $1.04-12.5^{d}$ & Londsdale et al. (1996) \\
\hline Calanus pacificus & Natural assemblage & 4.81 & - & $12.6-32.4$ & Fessenden \& Cowles (1994) \\
\hline \multirow{3}{*}{ C. finmarchicus } & Natural assemblage & $2.4-11.0$ & - & $7-24.5^{d}$ & Ohman \& Runge (1994) \\
\hline & Ciliates $>30 \mu \mathrm{m}$ & - & - & 20.8 & Nejstgaard et al. (1997) \\
\hline & Ciliates < $30 \mu \mathrm{m}$ & - & - & $7.5^{r}$ & Nejstgaard et al. (1997) \\
\hline C. simillimus (CIII-CVI) & Natural assemblage & 5.5 & 1.4 & $0.78-3.55^{\circ}$ & Atkinson (1996) \\
\hline \multirow{2}{*}{ Centropages hamatus } & Natural assemblage & 1.73 & - & $0.46-0.81$ & Turner \& Granéli (1992) \\
\hline & Natural assemblage & $0.20-0.80$ & -_ & $1.35-5.21$ & Tiselius (1989) \\
\hline C. abdomnalis & Natural assemblage & $1.2-1.7$ & - & $1.2-7.1$ & Fessenden \& Cowles (1994) \\
\hline C.typicus & S. sulcatum & 3.3 & 13.9 & $5.36-58.1$ & Wiadnyana \& Rassoulzadeqan (1989) \\
\hline \multirow[t]{2}{*}{ Eucalanus pileatus (CIII-CIV) } & Natural assemblage & 56.7 & 1.3 & 5.4 & Verity \& Paffenhofer (1996) \\
\hline & Natural assemblage & 41.7 & 2.4 & 5.3 & Verity \& Paffenhöfer (1996) \\
\hline Neocalanus tonsus (CV) & Natural assemblage & 5.5 & 1.4 & $4.58^{\text {r }}$ & Atkinson (1996) \\
\hline N. plumchrus & Ciliates $>5 \mu \mathrm{m}$ & $1.06-2.59$ & - & $15.6-39.0$ & Gifford \& Dagg (1991) \\
\hline Pseudocalanus sp. & Natural assemblage & 7.37 & - & $4.8-7.4$ & Fessenden \& Cowles (1994) \\
\hline \multirow[t]{2}{*}{ Temora longicornis } & S. acuminatum & $\sim 14.6$ & $72.03^{\mathrm{a}}$ & 3.85 & Hansen et al. (1996) \\
\hline & S. elegans & -46.2 & $22.76^{\mathrm{a}}$ & 1.38 & Hansen et al. (1996) \\
\hline \multicolumn{6}{|l|}{ Marine cyclopoid copepods } \\
\hline Oithona spp. (CIV-CVI) & Natural assemblage & 5.5 & 1.4 & $0.13^{d}$ & Atkinson (1996) \\
\hline \multicolumn{6}{|l|}{ Freshwater calanoid copepods } \\
\hline Acanthodiaptomus & Paramecium aurelia & $1.62-6.87$ & 103.4 & $0.87-2.62$ & Hartmann et al. (1993) \\
\hline \multirow[t]{2}{*}{ denticornis } & P. caudatum & $1.84-9.18$ & 154.8 & $1.29-2.93$ & Hartmann et al. (1993) \\
\hline & Loxodes sp. & 1.95 & 403.0 & $0.55-0.30$ & Hartmann et al. (1993) \\
\hline \multirow{2}{*}{$\begin{array}{l}\text { Diaptomus pygmaeus } \\
\text { (N5-N6) } \\
(\mathrm{N} 5-\mathrm{N} 6)\end{array}$} & Strobslidium velox & $1.9-5.2$ & 46 & $2.08-2.25$ & Burns \& Gilbert (1993) \\
\hline & Strob. velox & 5.2 & 46 & 0.25 & Burns \& Gilbert (1993) \\
\hline \multirow{6}{*}{$\begin{array}{l}\text { (N5-N6) } \\
\text { Diaptomus minutus } \\
\text { (N5-N6) } \\
\text { (N5-N6) } \\
\text { (CII-CII) } \\
\text { Epischura lacustris }\end{array}$} & Strombidium $\mathrm{sp}$. & 0.7 & $3.76^{\mathrm{b}}$ & 0.55 & Burns \& Gilbert (1993) \\
\hline & Strob velox & $0.7-5.2$ & 46 & $0.5-2.38^{d}$ & Burns \& Gilbert (1993) \\
\hline & Strob, velox & 5.2 & 46 & 0.27 & Burns \& Gilbert (1993) \\
\hline & Strombidium sp. & 0.7 & $3.76^{\mathrm{b}}$ & 0.51 & Burns \& Gilbert (199.3) \\
\hline & Strobilidium sp. 1 & 0.6 & $2.63^{b}$ & 0.97 & Burns \& Gillbert (1993) \\
\hline & Strob. velox & $0.8-1.9$ & 46 & $6.25-19.1^{\mathrm{d}}$ & Burns \& Gilbert (1993) \\
\hline \multicolumn{6}{|c|}{ Freshwater cyclopoid copepods } \\
\hline Cyclops abyssorum & Askenasia volvox & 2 & - & $1.25^{\mathrm{cd}}$ & Wickham $\{1995\}$ \\
\hline & Coleps hisrtus & 2 & - & $0.7^{n d}$ & Wickham $(1995)$ \\
\hline & Halteria grandinella & 5 & - & $0.20^{\text {cd }}$ & Wickham (1995) \\
\hline & Stokesia vernalis & 2 & - & $0.8^{\text {cd }}$ & Wickham (1995) \\
\hline & Strob velox & 2 & - & 1.7 od & Wickham (1995) \\
\hline C. kolensis & A. volvox & 2 & - & $3.12^{\text {ed }}$ & Wickham (1995) \\
\hline & C. hisrtus & 2 & - & $0.55^{\text {cd }}$ & Wickham (1995) \\
\hline & H. grandinella & 10 & - & $0.37^{\text {cd }}$ & Wickham (1995) \\
\hline & S. vernalis & 2 & - & $20^{\text {cd }}$ & Wickham (1995) \\
\hline & Strob. velox & 2 & - & $g^{\text {rd }}$ & Wickham (1995) \\
\hline
\end{tabular}


should be noted that swimming with rapid jumps is not exclusively found among mixotrophic oligotrichs and that in general swimming speeds increase with cell size.

At present, while data on copepod grazing on heterotrophic ciliates is considerable, data on grazing on mixotrophic species is sparse, and largely consists of recent studies on freshwater forms. These studies have concerned cyclopoid copepods and grazing rates did not appear to markedly differ between mixotrophs and heterotrophs. Wickham (1995) reported maximum filtration rates by cyclopoid copepods on 2 freshwater mixotrophic ciliates (Askenasia volvox and Stokesia vernalis) intermediate to rates estimated for heterotrophic species in the same experiments. Similarly, the mixotrophic Strombidium viridae was grazed at intermediate rates, relative to those recorded based on the disappearance of heterotrophic ciliates, by Diacyclops thomasi (Dobberfuhl et al. 1997). The lack of distinct differences between capture rates may be due to the fact that cyclopoid copepods are exclusively raptorial feeders. Data for marine organisms appears to be limited to a single study and concerns the mixotrophic oligotrich Strombidium reticulatum (Table 4). The maximum filtration rate of Acartia tonsa estimated on this ciliate by Jonsson \& Tiselius (1990) was about half the filtration rate on the heterotrophic ciliate used in the experiments but the heterotrophic ciliate was considerably larger

Although further investigation is clearly needed, our data suggests that copepod grazing may have a considerable effect on ciliate community composition (mixotrophy vs heterotrophy). However, the effect may be species specific and thus very difficult to predict. Copepod capture rates vary with the size and mobility of the prey, and these characteristics may vary inconsistently with the trophic type of ciliate. Furthermore, the relative importance of such differences in prey characteristics or qualities probably varies with the feeding strategy employed by the copepod, i.e. filter or raptorial feeding, which can in turn vary with abiotic factors such as turbulence in some species of copepod (e.g. Kiorboe et al. 1996).

Concerning the growth capacities of oligotrich ciliates, we expected a difference between heterotrophic and mixotrophic ciliates because one trophic type would be at a disadvantage under a given set of circumstances. However, roughly similar net growth rates were estimated for the similar-sized nanomixotroph and nanoheterotroph in our experiments. Another manner of investigating this question is to consider maximum growth rates. Mixotrophic oligotrichs may profit from both phagotrophy and photosynthesis to survive in food-poor conditions at the price of forsaking rapid growth under food-rich conditions.
To investigate this question we compared the maximum observed growth rates given in the literature for mixotrophic and heterotrophic oligotrich ciliates (Table 5, Fig. 4). We used multiple regression analysis where growth rate is a function of temperature and volume using a model of this type: $\ln \mu=a \ln T+$ $b \ln V+c$ (Fenchel 1968, Finlay 1977, Montagnes et al. 1988, Müller \& Geller 1993, Montagnes 1996). Results of the analysis are given in Table 6 ; for both mixotrophic and heterotrophic oligotrichs, maximum observed growth rates were highly correlated with temperature and relatively weakly with cell volume. We compared the multiple regression equations of heterotrophs and mixotrophs following Zar (1984). First, we tested if the 2 regression equations came from the same statistical population, and the F-test indicated that the regression equations differ significantly $\left(F_{\text {obs }}=4.58, \mathrm{p}<0.01, \mathrm{df} 3,34\right)$. To determine the origin of these differences, we tested the parallelism of planes defined by the multiple regression coefficients $a$ and $b$ corresponding to the terms associated with temperature and cell volume; the F-test indicated insignificant differences $\left(F_{\text {obs }}=1.64 \mathrm{df}\right.$ 1.34). We then examined the differences in the $c$ coefficient of hetero- and mixotrophs and the F-test of elevation was highly significant $\left(F_{\mathrm{obs}}=12.2, \mathrm{p}<\right.$

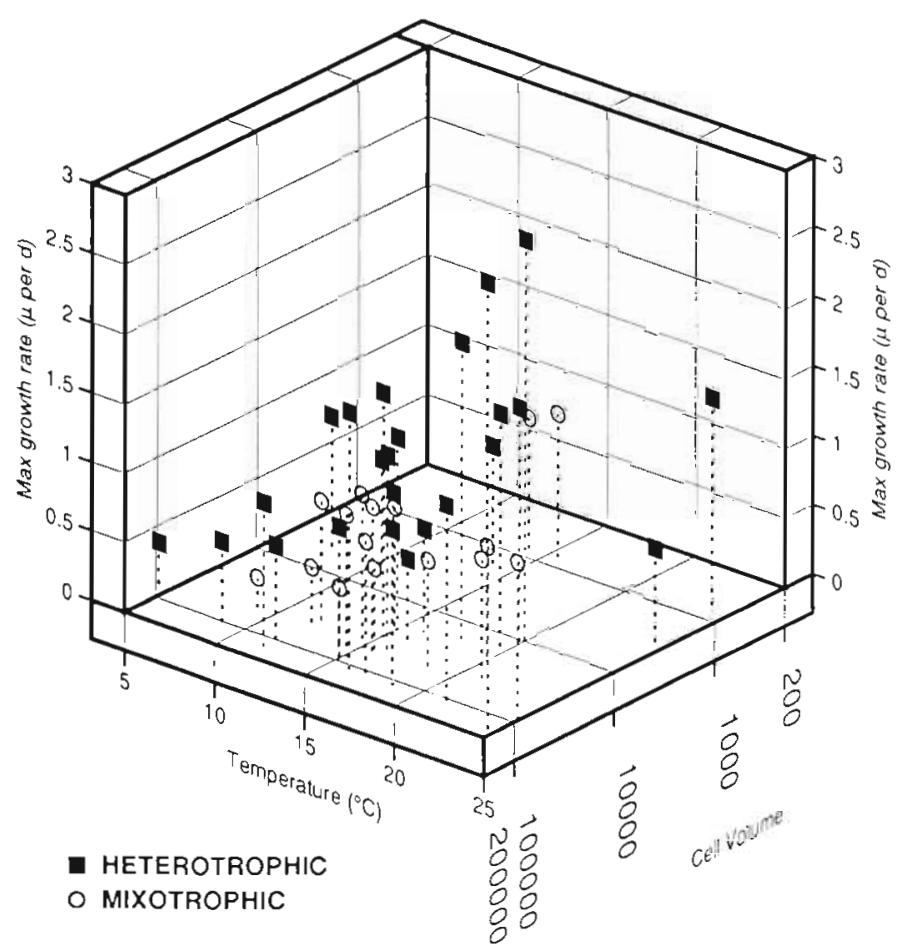

Fig. 4. Influence of temperature and cell volume on maximum observed growth rates of mixotrophs and heterotrophs. Data from Table 5 
0.01 , df 1.36 ), indicating that the elevations of planes, defined by coefficient $c$, are significantly different for mixotrophs and heterotrophs. Consequently, the effects of cell size and temperature are indistinguishable among mixotrophs and heterotrophs but lower maximum growth rates are predicted for mixotrophic oligotrichs.

The magnitude of the differences are shown in Fig. 5 in which maximum growth rates are plotted as a function of cell size at $15^{\circ} \mathrm{C}$; regardless of cell volume, mixotrophs appear to have a maximum growth rate of about 0.5 generations $\mathrm{d}^{-1}$ less than similar-sized heterotrophic oligotrichs. Our analysis suggests that mixotrophic growth is inherently limited by their metabolism, although temperature and cell volume effects are exerted in the same way as in heterotrophic oligotrichs. Thus, the price of mixotrophy may be about 0.5 generations $\mathrm{d}^{-1}$ in food-rich conditions. This may explain the incomplete dominance of mixotrophs, especially in food-rich environments.

Table 5. Maximum observed growth rates $\left(\mu_{\max }\right)$ of hetero- and mixotrophic oligotrichs from the literature. $\mu_{15^{\circ} \mathrm{c}}$ : estimated maximum growth rate at $15^{\circ} \mathrm{C}$ using the multiple regression equations we established for hetero-and mixotrophic ciliates. Volume: live volume

\begin{tabular}{|c|c|c|c|c|c|c|}
\hline Species & $\begin{array}{l}\text { Volume } \\
\left(\mu \mathrm{m}^{3}\right)\end{array}$ & $\begin{array}{l}\text { Temp } \\
\left({ }^{\circ} \mathrm{C}\right)\end{array}$ & $\begin{array}{l}\mu_{\max } \\
\left(d^{-1}\right)\end{array}$ & $\begin{array}{l}\mu_{159} \mathrm{C} \\
\left(\mathrm{d}^{-1}\right)\end{array}$ & Source & Location \\
\hline \multicolumn{7}{|l|}{ Heterotrophic oligotrichs } \\
\hline Halteria gradinella & 17736 & 20 & 1.73 & 1.20 & Taylor $(1978)$ & Ontario \\
\hline L. spiralis & $93400^{d}$ & 18 & 1.06 & 1.05 & Sheldon et al. (1986) & Mediterranean \\
\hline L. spiralis & 150000 & 12 & 1.06 & 1.01 & Jonsson $(1986)$ & Laboratory \\
\hline Strobilidium spiralis & 11494 & 20 & $1.7^{\mathrm{b}}$ & 1.24 & Verity (1991) & Laboratory \\
\hline Strobilidium sp. & $800^{\circ}$ & 24.3 & 1.55 & 1.54 & Dolan (1991) & Chesapeake Bay \\
\hline \multirow[t]{6}{*}{ Strobilidium lacustris } & 113000 & 5.5 & 0.43 & 1.03 & \multirow{6}{*}{ Müller \& Geller (1993) } & \multirow[t]{6}{*}{ Laboratory } \\
\hline & 113000 & 9 & 0.60 & 1.03 & & \\
\hline & 113000 & 12 & 0.70 & 1.03 & & \\
\hline & 113000 & 15.5 & 0.99 & 1.03 & & \\
\hline & 113000 & 18.5 & 1.38 & 1.03 & & \\
\hline & 113000 & 21.5 & 1.42 & 1.03 & & \\
\hline Strobilidium neptuni & 110000 & 16 & 1.84 & 1.04 & Montagnes (1996) & Laboratory \\
\hline Strobilidium venilae & 19635 & 16 & 0.73 & 1.19 & Montagnes (1996) & Laboratory \\
\hline Strombidinopsis cheshiri & 45815 & 16 & 0.99 & 1.11 & Montagnes et al. (1996) & \multirow{2}{*}{ Chesapeake Bay } \\
\hline Strombidium sp. & $\begin{array}{l}4800^{\circ} \\
4800^{a}\end{array}$ & 10.2 & 0.75 & 1.33 & Dolan (1991) & \\
\hline \multirow[t]{2}{*}{ Strombidium sp. } & 24017 & $20^{.4}$ & $\begin{array}{l}0.94 \\
2.71\end{array}$ & $\begin{array}{l}1.33 \\
1.17\end{array}$ & \multirow{2}{*}{ Ohman \& Snyder (1991) } & \multirow{2}{*}{ Laboratory } \\
\hline & 24017 & 15 & 1.38 & 1.17 & & \\
\hline Strombidium sp. b & 1722 & 1.3 .9 & 0.86 & 1.44 & This study & Ligurian Sea \\
\hline Strombidium B & - & - & 1.2 & - & Verity et al. (1993) & North Atlantıc \\
\hline S. acuminatum & 393300 & 25 & 0.74 & 0.77 & Tumantseva \& Kopylov (1985) & Peru \\
\hline S. siculum & 28575 & 16 & 0.57 & 1.15 & Montagnes (1996) & Laboratory \\
\hline S. sulcatum & 33500 & 15 & 1.75 & 1.14 & Rivier et al. (1985) & Laboratory \\
\hline S. sulcatum & 10000 & 20 & 2.88 & 1.25 & Fenchel \& Jonsson (1988) & Laboratory \\
\hline S. sulcatum & 19000 & 18 & 2.16 & 1.19 & Allali et al. (1994) & Laboratory \\
\hline \multicolumn{7}{|l|}{ Mixotrophic oligotrichs } \\
\hline Laboea strobila & 78000 & 15 & $\sim 1$ & 0.72 & Stoecker et al. (1988) & Laboratory \\
\hline L. strobila & 91000 & 15 & 0.5 & 0.71 & Putt \& Stoecker (1989) & Laboratory \\
\hline L. strobila & $134000^{\mathrm{d}}$ & $17.4^{\mathrm{b}}$ & $1.0^{\mathrm{b}}$ & 0.69 & Nielsen \& Kiørboe (1994) & Kattegat \\
\hline \multirow[t]{5}{*}{ Pelagostrombidium fallax } & 50000 & 9 & 0.21 & 0.74 & \multirow[t]{5}{*}{ Müller \& Geller (1993) } & \multirow[t]{5}{*}{ Laboratory } \\
\hline & 50000 & 12 & 0.42 & 0.74 & & \\
\hline & 50000 & 15.5 & 0.57 & 0.74 & & \\
\hline & 50000 & 18.5 & 0.76 & 0.74 & & \\
\hline & 50000 & 21.5 & 0.90 & 0.74 & & \\
\hline \multirow[t]{2}{*}{ Strombidium sp. a } & $740^{\circ}$ & 15.5 & 1.03 & 1.04 & \multirow[t]{2}{*}{ This study } & \multirow{2}{*}{ Ligurian Sea } \\
\hline & $740^{\circ}$ & 13.9 & 0.93 & 1.04 & & \\
\hline Strombidium A & - & - & 1.1 & - & Verity et al. (1993) & North Atlantic \\
\hline \multirow[t]{2}{*}{ S. capitatum } & $54199^{\circ}$ & 15 & 1.09 & 0.74 & Stoecker \& Silver (1990) & \multirow{2}{*}{$\begin{array}{l}\text { Laboratory } \\
\text { Laboratory }\end{array}$} \\
\hline & 64140 & 16 & 1.07 & 0.73 & Montagnes (1996) & \\
\hline \multirow[t]{2}{*}{ S. conicum } & 92800 & 25 & 1.13 & 0.71 & Tumantseva \& Kopylov (1985) & \multirow{2}{*}{$\begin{array}{l}\text { Laboratory } \\
\text { Laboratory }\end{array}$} \\
\hline & 25550 & 15 & 0.88 & 0.79 & Putt \& Stoecker (1989) & \\
\hline S. oculatum & $48800^{\mathrm{d}}$ & - & 0.65 & - & Jonsson (1994) & St. Malo Bay \\
\hline S. reticulatum & 40000 & 12 & 0.86 & 0.76 & Jonsson (1986) & Laboratory \\
\hline Tontonia gracilluma & 150100 & 24.5 & 1.30 & 0.68 & Tumantseva \& Kopylov (1985) & Laboratory \\
\hline
\end{tabular}




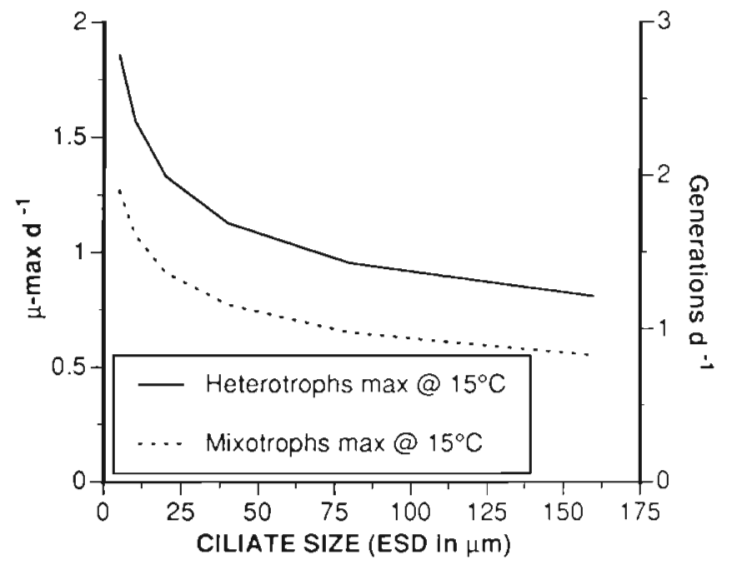

Fig. 5. Maximum growth rate ( $\mu$-max) of mixo- and heterotrophic ciliates calculated at $15^{\circ} \mathrm{C}$ as a function of cell size using the multiple regression equations shown in Table 6 . Note that calculated maximum growth rates for mixotrophic oligotrichs are about 0.5 generations $\mathrm{d}^{-1}$ lower than those estimated for heterotrophic oligotrichs

Table 6. Multiple regression analysis of data presented in Table 5 and Fig. 4 , using the model $\ln \mu=a \ln T+b \ln V+c$. $n$ : number of data used. p: probability associated to constants $a$ and $b$ and to $\mathrm{R}^{2} a$ and $b$ coefficients for heterotrophs and mixotrophs were not significantly different: $F_{\text {parallehsm }}=1.64$ (df 1,34); but $c$ coefficients were significantly different: $F_{\text {eievation }}=12.2($ df 1,36$) \mathrm{p}<0.01$

\begin{tabular}{|lclllc|}
\hline Group & $\mathrm{n}$ & \multicolumn{1}{c}{$\mathrm{R}^{2}$} & \multicolumn{1}{c}{$a$} & \multicolumn{1}{c|}{$b$} & $c$ \\
\hline Mixotrophs & 16 & 0.58 & 1.4 & -0.08 & -3.22 \\
$\mathrm{p}$ & & 0.0035 & 0.001 & 0.1552 & \\
Heterotrophs & 24 & 0.45 & 0.85 & -0.08 & -1.34 \\
$\mathrm{p}$ & & 0.0018 & 0.0009 & 0.0984 & \\
All groups & 40 & 0.39 & 0.94 & -0.08 & -1.79 \\
$\mathrm{p}$ & & 0.0001 & 0.0001 & 0.0639 & \\
\hline
\end{tabular}

Acknowledgements. The work reported is part of the doctoral dissertation of M.T.P. We are indebted to $V$. Andersen for organising the DYNAPROC Cruise Program, P. Nival for supplying copepods, S. Nival for identifying copepods, F. Vidussi for generously providing chl a concentrations, L. Prieur and J. Raunet for providing CTD data, and the captain and crew of the 'Suroit' for ship operations. Financial support was provided by the C.N.R.S., the Commission of the European Communities through the contract 'MEDEA' (MAS3 CT95-0016) and a Eusko Jaurlaritza (Basque government) grant to M.T.P. We are indebted to the reviewers of previous versions of this paper and Dr Stoecker; the manuscript was greatly improved as a result of their comments.

\section{LITERATURE CITED}

Allali K, Dolan JR, Rassoulzadegan F (1994) Culture characteristics and orthophosphate excretion of a marine oligotrich ciliate, Strombidium sulcatum, fed heat-killed bacteria. Mar Ecol Prog Ser 105:159-165
Atkinson A (1996) Subantarctic copepods in an oceanic, low chlorophyll environment: ciliate predation, food selectivity and impact on prey populations. Mar Ecol Prog Ser 130: $85-96$

Ayukai T (1987) Predation by Acartia clausi (Copepoda: Calanoida) on two species of tintinnids. Mar Microb Food Webs 2:45-52

Beers JR, Reid MA, Stewart GL (1980) Microplankton population structure in Southern California nearshore waters. Mar Biol 60:209-226

Berggreen U, Hansen B, Kiørboe T (1988) Food size spectra, ingestion and growth of the copepod Acartia tonsa during development: implications for determination of copepod production. Mar Biol 99:341-352

Bernard C. Rassoulzadegan F (1994) Seasonal variations of mixotrophic ciliates in the northwest Mediterranean Sea. Mar Ecol Prog Ser 108:295-301

Burns CW, Gilbert JJ (1993) Predation on ciliates by freshwater calanoid copepods: rates of predation and relative vulnerabilities of prey. Freshwat Biol 30:377-393

Buskey EJ, Coulter C. Strom S (1993) Locomotory patterns of microzooplankton: potential effects on food selectivity of larval fish. Bull Mar Sci 53:29-43

Crawford DW (1992) Metabolic cost of motility in planktonic protists: theoretical considerations on size scaling and swimming speed. Microb Ecol 24:1-10

Dobberfuhl DR, Miller RM, Elser JJ (1997) Effects of a cyclopoid copepod (Diacyclops thomasi) on phytoplankton and the microbial food web. Aquat Microb Ecol 12:29-37

Dolan JR (1991) Microphagous ciliates in mesohaline Chesapeake Bay waters: estimates of growth rates and consumption by copepods. Mar Biol 11:303-309

Dolan JR, Marrasé C (1995) Planktonic ciliate distribution relative to a deep chlorophyll maximum: Catalan Sea, NW Mediterranean, June 1993. Deep Sea Res 42:1965-1987

Fenchel $T$ (1968) The ecology of marine microbenthos. III The reproductive potential of ciliates Ophelia 5:123-136

Fenchel T, Jonsson PR (1988) The functional biology of Strombidium sulcatum, a marine oligotrich ciliate (Ciliophora, Oligotrichina). Mar Ecol Prog Ser 48:1-15

Fessenden L, Cowles TJ (1994) Copepod predation on phagotrophic ciliates in Oregon coastal waters. Mar Ecol Prog Ser 107:103-111

Finlay BJ (1977) The dependence of reproductive rate on cell size and temperature in freshwater ciliated protozoa Oecologia 30:75-81

Frost BW (1972) Effects of size and concentration of food particles on the feeding behavior of the marine planktonic copepod Calanus pacificus. Limnol Oceanogr 17:805-815

Gifford DJ (1991) The protozoan-metazoan trophic link in pelagic ecosystems. J Protozool 38:81-86

Gifford DJ, Dagg MJ (1988) Feeding of the estuarine copepod Acartia tonsa Dana: carnivory vs herbivory in natural microplankton assemblages. Bull Mar Sci 43:458-468

Gifford DJ, Dagg MJ (1991) The microzooplankton-mesozooplankton link: consumption of planktonic protozoa by the calanoid copepods Acartia tonsa Dana and Neocalanus plumchrus Murukawa. J Plankton Res 5:161-177

Gilbert JJ (1994) Jumping behavior in the oligotrich ciliates Strobilidium velox and Halteria grandinella, and its significance as a defence against rotifer predators. Microb Ecol $27: 189-200$

Hansen B, Christiansen S, Pedersen G (1996) Plankton dynamics in the marginal ice zone of the central Barents Sea during spring: carbon flow and structure of the grazer food chain. Polar Biol 16:115-128

Hartmann HJ, Taleb H, Aleya L, Lair N (1993) Predation on 
ciliates by the suspension-feeding calanord copepod Acanthodiaptomus denticornis. Can J Fish Aquat Sci 50 $1382-1393$

Jonsson PR (1986) Particle size selection, feeding rates and growth dynamics of marine planktonuc oligotrichous ciliates (Ciliophora: Oligotrichina). Mar Ecol Prog Ser 33: 265-277

Jonsson PR (1994) Tidal rhythm of cyst formation in the rock pool ciliate Strombidium oculatum Gruber (Ciliophora Oligotrichida): a description of the functional biolngy and an analysis of the tidal synchronisation of encystment. J Exp Mar Biol Ecol 175:77-103

Jonsson PR, Tiselius P (1990) Feeding behaviour, prey detection and capture efficiency of the copepod Acartia tonsa feeding on planktonic ciliates. Mar Ecol Prog Ser 60:35-44

Kiørboe T, Salz E, Viitasalo M (1996) Prey switching behaviour in the planktonic copepod Acartia tonsa. Mar Ecol Prog Ser 143:65-75

Landry MR (1994) Methods and controls for measuring the grazing impact of planktonic protists. Mar Microb Food Webs 8:37-57

Laval-Peuto M, Rassoulzadegan F (1988) Autofluorescence of marine planktonic Oligotrichına and other culiates. Hydrobiologia 159:99-110

Leakey RJG, Burkill PH, Sleigh MA (1994) Ciliate growth rates from Plymouth Sound: comparison of direct and indirect estimates. J Mar Biol Assoc UK 74:849-861

Lonsdale DJ, Cosper EM, Kım W, Doall M, Divadeenam A, Jonassdottir SH (1996) Food web interactions in the plankton of Long Island bays, with preliminary observations on brown tide effects. Mar Ecol Prog Ser 134:247-263

Montagnes DJS (1996) Growth responses of planktonic clliates in the genera Strobilidium and Strombidium. Mar Ecol Prog Ser 130:241-254

Montagnes DJS, Berger JD, Taylor FJR (1996) Growth rate of the marine planktonic ciliate Strombidinopsis cheshir Snyder and Ohman as a function of food concentration and interclonal variability. J Exp Mar Biol Ecol 206: $121-132$

Montagnes DJS, Lynn DH (1991) Taxonomy of choreotrichs, the major marine planktonic ciliates, with emphasis on the aloncate forms. Mar Microb Food Webs 5:59-74

Montagnes DJS, Roff JC. Taylor WD (1988) The annual cycle of heterotrophic planktonic cllates in the water surrounding the Isles of Shoals, Gulf of Maine: assessment of their trophic role. Mar Biol 99:21-30

Muller $H$, Geller W (1993) Maximum growth rates of aquatic cliated protozoa: the dependence on body size and temperature reconsidered. Arch Hydrobiol 126:315-327

Nejstgaard JC, Gismervk I, Solberg PT (1997) Feeding and reproduction by Calanus finmarchicus, and microzooplankton grazing during mesocosm blooms of diatoms and the coccolithophore Emiliania huxley. Mar Ecol Prog Ser 147:197-217

Nielsen TG, Kiørboe T (1994) Regulation of zooplankton biomass and production in a temperate, coastal ecosystem. 2. Ciliates. Limnol Oceanogr 39:508-519

Nival P, Nival S (1973) Efficacite de fultration des copépodes planctoniques. Ann Inst oceanogr, Paris 49:135-144

Ohman MD, Runge JA (1994) Sustained fecundity when phytoplankton resources are in short supply: omnivory by Calanus finmarchicus in the Gulf of St. Lawrence. Limnol Oceanogr 39:21-36

Ohman MD, Snyder RA (1991) Growth kinetics of the omnivorous oligotrich ciliate Strombidium sp. Limnol Oceanogr $36: 922-935$

Putt M. Stoecker DK (1989) An experimentally determined carbon: volume ratio for marine 'oligotrichous' ciliates from estuarine and coastal waters. Limnol Oceanogr 34 $1097-1103$

Rivier A, Brownlee DC, Sheldon RW, Rassoulzadegan F (1985) Growth of microzooplankton: a comparative study of bacterivorous zooflacjellates and ciliates. Mar Microb Food Webs 1:51-60

Robertson JR (1983) Predation by estuarine zooplankton on tıntınnid cillates. Estuar Coast Shelf Sci 16:27-36

Sheldon RW, Nival P, Rassoulzadegan F (1986) An experimental investigation of a flagellate-ciliate-copepod food chain with some observations relevant to the linear biomass hypothesis. Limnol Oceanogr $31 \cdot 184-188$

Sherr EB, Sherr BF, Paffenhöfer GA (1986) Phagotrophic protozoa as food for metazoans: a 'missing' trophic lnk in marine pelagic food webs? Mar Microb Food Webs 1. $61-80$

Stoecker DK (1991) Mixotrophy in marine planktonic ciliates: physiological and ecological aspects of plastid-retention by oligotrichs. In: Reid PC, Turley CM, Burkill PH (eds) Protozoa and their role in marine processes. NATO ASI Ser G. Springer-Verlag, Berlin, p 161-179

Stoecker DK, Capuzzo JM (1990) Predation on protozoa: its importance to zooplankton. J Plankton Res 12:891-908

Stoecker DK, Egloff DA (1987) Predation by Acartia tonsa on planktonıc ciliates and rotifers. J Exp Mar Biol Ecol 110 $53-68$

Stoecker DK, Gifford, DJ, Putt M (1994) Preservation of manne planktonic cillates: losses and cell shrinkage during fixation. Mar Ecol Prog Ser 110:293-299

Stoecker DK, Michaels AE, Davis LH (1987) Large proportion of marine planktonic ciliates found to contain functional chloroplasts Nature 326:790-792

Stoecker DK, Sanders NK (1985) Differential grazing by Acartia tonsa on a dinoflagellate and a tintinnid. J Plankton Res $7: 85-100$

Stoecker DK. Silver MW (1990) Replacement and ageıng of chloroplasts ın Strombidıum capitatum (Ciliophora: Oligotrichidat. Mar Biol 107:491-502

Stoecker DK, Silver MW, Michaels AE, Davis LH (1988) Obligate mixotrophy in Laboea strobila, a ciliate which retains chloroplasts. Mar Biol 99:415-423

Stoecker DK, Tanuguchı A, Michaels AE (1989) Abundance of autotrophıc, mixotrophic and heterotrophic planktonic ciljates in shelf and slope waters. Mar Ecol Prog Ser 50: $241-254$

Taylor DW (1978) Maxımum growth rate, size and commonness in a community of bactivorous cillates. Oecologia 36 : $263-272$

Tiselius P (1989) Contribution of aloncate culiates to the diet of Acartia clausi and Centropages hamatus in coastal waters. Mar Ecol Prog Ser 56:49-56

Tumantseva NI, Kopylov AI (1985) Reproduction and producthon rates of planktonic infusoria in coastal waters of Peru. Oceanology 25:390-394

Turner JT, Anderson DM (1983) Zooplankton grazing during dinoflagellate blooms in a Cape Cod embayment, with observations of predation upon tintinnids by copepods. Mar Ecol 4:359-374

Turner JT, Granéli E (1992) Zooplankton feedung ecology: grazing during enclosure studies of phytoplankton blooms from the west coast of Sweden. J Exp Mar Bıol Ecol 157 : 19-31

Verity PG (1991) Measurement and simulation of prev uptake by marine planktonic ciliates fed plastidic and aplastidic nanoplankton. Limnol Oceanogr 36:729-750

Verity $P G$, Paffenhofer G (1996) On assessment of prey inges- 
tion by copepods. J Plankton Res 18:1767-1779

Verity PG, Stoecker DK, Sieracki ME, Nelson JR (1993) Grazing, growth and mortality of microzooplankton during the 1989 North Atlantic spring bloom at $47^{\circ} \mathrm{N}, 18^{\circ} \mathrm{W}$. Deep Sea Res 40:1793-1814

Wiadnyana NN, Rassoulzadegan F (1989) Selective feeding of Acartia clausi and Centropages typicus on microzoo-

This article was presented by Diane Stoecker (Senior Editorial Advisor), Cambridge, Maryland, USA plankton. Mar Ecol Prog Ser 53:37-45

Wickham SA (1995) Cyclops predation on ciliates: speciesspecific differences and functional responses. J Plankton Res 17:1633-1646

Zar JH (1984) Biostatistical analysis. Comparison of multiple regression equations. Prentice-Hall International, New York, p 347-349

Manuscript received: November 30, 1996 Revised version accepted: June 10,1997 